be placed on record, especially as his notes are very definite, and there could have been no known possibility of mistake.

Unless the unknown body was one of the brighter asteroids-and Ceres, Pallas, Juno, and Vesta were known to be elsewhere-the result is, as yet, entirely incomprehensible.

The Rio de Janeiro OBservatory.-We have just received the "Annuario" of the Rio de Janeiro Observatory for 1906, a useful volume which is published by the observafory, under the direction of the Minister of Industry and of Public Works, and which is the twenty-second of the series.

In addition to the usual calendars and tables of astronomical events, this volume contains numerous tables employed in astronomical reductions and conversions, tables for the reduction of meteorological observations, data employed in physical and chemical operations, and a résumé of the meteorological observations made in the Rio de Janeiro area during the year 1904.

\section{IRON AND STEEL INSTITUTE.}

T $N$ place of the usual autumn meeting, the Iron and Steel Institute held a largely attended meeting in London on July 24 and following days jointly with the American Institute of Mining Engineers. At the opening meeting the president of the Iron and Steel Institute, Mr. R. A. Hadfield, gave an address of welcome to the American guests, expressing satisfaction that so many American engineers had been able to be present at this important international meeting. Sir James Kitson, who was president when the saciety first visited America in 1890 , followed with a similar address of cordial weicome. Mr. Robert Hunt, president of the American society, in acknowledgment, said they felt as though they were part of the Iron and Steel Institute in that their society was formed on the same lines, and was equally camprehensive in its character and membership. The president announced that the King had consented to receive a deputation of the American guests, and also to honour the institute by accepting the Bessemer gold medal. $\mathrm{He}$ also amrounced that Sir Hugh Bell had been unanimously elected as his successor to the presidency in May next. Papers on Continental practice in blast-furnace gas engines were then read in abstract by the secretary, Mr. Bennett H. Brough. The first of these, by Prof. Hubert (Liege), dealt with the design of blast-furnace gas engines in Belgium. It reviewed the history of the direct utilisation of blast-furnace gas in engines since the early attempts in I895, and gave particulars of detailed tests of a I400 horsepower two-cylinder double-acting and tandem engine made by the Cockerill Company. Mr. Reinhardt's paper, on the application of large gas engines in the German iron and sfeel industries, formed an exhaustive treatise on the subject. The author showed that in the German ironworks there are 349 gas engines with a total effective horse-power of 385,000 . He reviewed the practical experience gained by working, and with the aid of a large number of illustrations explained the present design of large gas engines in Germany. The old arrangement of the single-acting fourcycle motor, with one or more cylinders, has in recent years not been generally used, and, on the other hand, doubleacting four-cycle motors, mostly with tandem cylinders, are in keen competition with two-cycle motors. The author described in detail the cylinder and exhaust-valve chest, valve gear, shifting boxes, cooled pistons and piston rods, ignition and starting, and various engines of the doubleacting four-cycle type of the leading German makers, the remainder of the paper being devoted to two-cycle engines on the Oechelhäuser and the Körting systems. Suitable trials concerning the consumption of gas, Mr. Reinhardt remarked, are not available for comparison, and therefore it is not yet known how far the two-cycle engine is at the present time in this respect still inferior to the four-cycle engine. In conclusion, the author stated that the present position of the application of gas engines in German ironwarks shows the value the managers of these undertakings aftribute to the better and less dangerous utilisation of the waste gases of their furnaces.

No. I918, voL. 74 ]
Mr. T. Westgarth (Middlesbrough) followed with a paper on large gas engines built in Great Britain. All the British builders were, he said, using the four-cycle system, except the builders of the Körting and Oechelhäuser engines, who worked on the two-cycle system.

In discussion, Mr. Julian Kennedy pointed out that in the United States gas engines were only in their infancy. After further well-sustained discussion, the meeting adjourned. During the afternoon visits were paid to the National Physical Laboratory, to the London County Council's electricity generating station at Greenwich, to the Mercers' Hall, and to the Hall of the Armourers' and Brasiers' Company, and in the evening a reception was given by the Lord Mayor at the Mansion House.

On July 25 a crowded meeting was presided over by $\mathrm{Mr}$. Robert W. Hunt (Chicago), president of the American Institute of Mining Engineers. His presidential address dealt chiefly with American rolling-mill practice, and concluded with the announcement that Mr. J. E. Stead, F.R.S., and Mr. R. A. Hadfield had been elected honorary members of the American society. The first paper read dealt with a comparison of American and foreign rail specifications, with a proposed standard specification to cover American rails rolled for export. The author, $\mathrm{Mr}$. A. L. Colby, read the paper in abstract, and the proposal to admit $0 \cdot 1$ per cent. of phosphorus was adversely criticised by Mr. Windsor Richards and other British members, the 0.07 per cent. recommended by the Engineering Standards Committee being considered safest for British practice. A paper by Mr. R. H. Lee, on producers in blast-furnace work, was briefly discussed, and the meeting adjourned. In the afternoon visits were paid to the works of Messrs. John I. Thornycroft at Chiswick, to the works of Messrs. $\mathrm{J}$. and E. Hall at Dartford, to the halls of the Inner and Middle Temples, to Kensington Palace, the Imperial Institute, and the museums at South Kensington. In the evening there was a fête at the Imperial Royal Austrian Exhibition at Earl's Court.

On July $26 \mathrm{Mr}$. Hunt occupied the chair, but upon his proposal Mr. Hadfield presided. The first paper taken was by $\mathrm{Mr}$. James P. Roe, on the development of the puddling process, and this was followed by a paper by $\mathrm{Mr}$. James E. York on improvements in rolling iron and steel. These two papers, which are of extreme importance from a practical point of view, elicited an excellent discussion. The remaining papers on the British and American lists were taken as read. Many of these are of great interest and value, and we hope to publish abstracts of them in a subsequent issue. During the afternoon, visits were paid to the works of Messrs. Fraser and Chalmers at Erith, to the works of the Associated Portland Cement Manufacturers at Northfleet, to the Chelsea Power Station, and to the hall of the Ironmongers' Company. In the evening there was a banquet and special firework display at the Crystal Palace.

On July 27 the King received at Buckingham Palace a deputation of the councils of the Iron and Steel Institute and of the American Institute of Mining Engineers, and accepted from the president, Mr. Hadfield, the Bessemer gold medal and a suitable illuminated address. The general body of members visited Windsor Castle, where special facilities were given them for seeing the palace and gardens. In the evening there was a banquet at the Guildhall; $\mathrm{Mr}$. Hadfield presided, and the company numbered 600 and included many distinguished guests. The American ladies, numbering 100 , were entertained at dinner in two of the committee rooms, with Mrs. Hadfield and Lady LloydWise presiding.

On July 28 there were alternative excursions to Messrs. Butlin's biast furnaces at Wellingborough and to the Dover harbour works. These two successful visits brought the Iron and Steel Institute meeting to a close. For the American guests visits were arranged, on Sunday, July 29, to St. Paul's Cathedral, the Roman Catholic Cathedral at Westminster, the Zoological Society's Gardens, the Botanic Society's Gardens, and to Hurlingham and Ranelagh Clubs, and on July 30 they started on a provincial tour, organised by the Iron and Steel Institute, to York, Ripon, Middlesbrough, Durham, Newcastle-on-Tyne, Glasgow, and Edinburgh. 